\title{
Soil loss and PM10 emissions from agricultural fields in the Junggar Basin over the past six decades
}

\author{
H. Pi, N.P. Webb, J. Lei, and S. Li
}

\begin{abstract}
The Junggar Basin in north Xinjiang Province is regarded as one of the important dust sources in China. There is, however, a lack of information on long-term dust emissions originating from the basin. In these largely agricultural communities, wind erosion is a major concern that results in a threat to sustainable agriculture and environmental quality. This study assesses dust emissions from the agricultural community of the Junggar Basin in north Xinjiang based on soil and land use types extracted from remote sensing data in response to weather and climate over the past six decades. The Wind Erosion Prediction System (WEPS) was used to simulate annual soil loss and PM10 (particulate matter $\leq 10 \mu \mathrm{m}$ in aerodynamic diameter) emissions at 11 meteorological stations across the Junggar Basin. From 1958 to 2018, annual soil loss and PM10 emissions significantly decreased 3.65 and $0.2 \mathrm{~kg} \mathrm{~m}^{-2} \mathrm{y}^{-1}$, respectively. This decrease was likely due to decreasing wind speed, but also associated with increased precipitation and temperature, and decreased solar radiation. Wind erosion occurred most frequently during April and May, accounting for 39\% of the annual soil loss and 40\% of the annual PM10 emission. In contrast, no erosion occurred in January, February, and December as a result of low temperature $\left(<-8.6^{\circ} \mathrm{C}\right)$, frozen soil conditions, and snow cover. Wind erosion risk appeared to decrease during the past six decades in response to observed climate change across the basin; however the southeast part of the basin experienced increasing wind erosion risk over the six decades. Projects to control wind erosion risk and combat dust emission should be given priority in the southeast part of the basin. Frequency of dust events was compared to simulated erosion; a strong linkage was found between simulated soil loss and frequency of dust storms based on regression analysis. This demonstrated that the modelling was acceptable in the conditions of this study and the results were prone to be reliable.
\end{abstract}

Key words: climate—dust emission-land use types — soil types-weather-WEPS

The Junggar Basin is a large endorheic basin occupying an area of 0.38 million $\mathrm{km}^{2}$ in north Xinjiang Province of northwestern China. The basin is characterized by a dry climate and scarce water sources due to the long distance from the sea. The region is surrounded by the Tarbagata mountain range to the northwest, Altai mountain range to the northeast, and Tian Shan mountain range to the south. These tall mountains typically intercept most atmospheric moisture transported toward the basin by prevailing westerly winds and greatly influence the atmospheric circulation across the region. Due to the influence of these tall mountains, the basin therefore is characterized by a desert environment. Nonetheless, gaps in the Altay and Tarbagata mountains in the northwestern part of the basin allow the intrusion of air masses by prevailing westerly winds. This intrusion of air results in a relatively cool and wet environment in the northwest part of the basin and contrasts with the relatively desert environment in the southwestern part of the basin.

About $37 \%$ of the Junggar Basin is covered by the Gurbantunggut Desert, which is the second largest desert in China. Aeolian loess is widely distributed on flat slopes between the Gurbantunggut Desert and the mountains around the basin (Fang et al. 2002). Agriculture is one of the dominant industries in the region. Most of the agricultural fields are irrigated to support cropping systems, although snowfall and snowmelt dominate hydrological processes in the region (Guo and $\mathrm{Li}$ 2015). Wind erosion is a major concern in the basin due to the excessive land exploitation within the semiarid environment (Qian et al. 2007; Shao and Dong 2006; Feng et al. 2011). Land management activities such as crop cultivation can have profound impacts on wind erosion processes (Webb and Pierre 2017). Wind erosion removes the most fertile part of the topsoil and causes land degradation and fugitive dust emissions, which threaten human and environmental health. In addition, wind erosion can negatively affect agricultural sustainability and commerce by reducing the productive potential of soils, as well as impact carbon (C) cycling and $\mathrm{C}$ stocks, reducing the potential benefits of adaptation strategies (Webb et al. 2017).

Severe wind erosion not only occurs in the desert environment of the basin, but also in agricultural communities. Soil properties in agricultural communities are finer as compared to desert environments. For example, sand fraction and the mean particle diameter are $72 \%$ and $366 \mu \mathrm{m}$, respectively, at a site in the center of the Gurbantunggut Desert (Yang et al. 2016). In contrast, sand fraction and the mean particle diameter are $32 \%$ and $35 \mu \mathrm{m}$, respectively, at an agricultural site on the southern edge of the Junggar Basin (Liu et al. 2012). In fact, dust emissions occurring from agricultural communities as compared

Huawei Pi (corresponding author) is a professor in the Key Research Institute of Yellow River Civilization and Sustainable Development and Collaborative Innovation Center for Yellow River Civilization, Henan University, China; he is also an adjunct soil scientist in the Xinjiang Institute of Ecology and Geography, Chinese Academy of Sciences, Urumqi, Xinjiang, China. Nicholas P. Webb is a soil scientist with the USDA Agricultural Research Service Jornada Experimental Range, MSC 3JER, New Mexico State University, Las Cruces, New Mexico, United States. Jiaqiang Lei is a soil scientist in the Xinjiang Institute of Ecology and Geography, Chinese Academy of Sciences, Urumqi, Xinjiang, China. Sisi Li (corresponding author) is an assistant professor in the Key Research Institute of Yellow River Civilization and Sustainable Development and Collaborative Innovation Center for Yellow River Civilization, Henan University, Henan, China.

Received January 29, 2021; Revised June 19, 2021; Accepted July 14, 2021. 
to desert environments have a greater impact on air quality and land management because dust emitted from agricultural lands is finer and can be suspended longer in the atmosphere. Evidence from previous studies (Liu 1985; Pécsi 1990; Ding et al. 1998) indicate that the Chinese Loess Plateau was derived from wind-blown silt deposits after millions of years of accumulation, and the Junggar Basin was one of their most important dust sources (Liu 1985). The primary soil particle size (i.e., 0.005 to $0.05 \mathrm{~mm}$ ) found in the Loess Plateau suggests that sediment of the plateau primarily derived from land surface features with fine soil texture such as bare land currently used for agricultural production, degraded meadows, and weathering of rocks, rather than desert environments (Liu 1985; Li et al. 2020c). Assessing wind erosion and dust emission in the Junggar Basin may be beneficial to understand the deposition of the Loess Plateau. The Chinese Loess Plateau is a large endorheic plateau (0.64 million $\mathrm{km}^{2}$ ) extending into seven provinces located in north China. The plateau is important to Chinese history as a result of the early cradles of Chinese civilization and main ancient agricultural area.

Recent studies indicated that Xinjiang Province has undergone an "unequivocal" change in climate (IPCC 2007; Scott et al. 2016; Fu et al. 2013; Deng et al. 2015). Precipitation and temperature have increased over the last 50 years at rates of $1.325 \mathrm{~mm}$ $\mathrm{y}^{-1}$ and $0.035^{\circ} \mathrm{C} \mathrm{y}^{-1}$, respectively (He et al. 2020). Climate change significantly impacts agricultural production, and soil wind erosion associated with land degradation threatens agroecosystems and increases their vulnerability to climate change in a cyclical pattern (Webb et al. 2017; Li et al. 2020a). Unfortunately, these interactions have largely been omitted from assessments of climate change impacting agricultural land management. It is necessary to know whether climate change impacts wind erosion in agricultural land and can be mitigated by adaptive management. Soil wind erosion is of particular importance in north Xinjiang Province as a result of this region being one of the most important sources of Asian dust. Quantifying soil loss and PM10 emission and interpreting likely responses to management is vital for identifying lands susceptible to wind erosion and identifying conservation practices to mitigate these hazards (Van Pelt et al. 2017).
The lack of long-term continuous observations of soil loss and PM10 emission has precluded assessing the intensity of aeolian processes and related wind erosion risk in the Junggar Basin response to long-term climate changes. There is little published work documenting windblown soil and PM10 loss for the Junggar Basin. Song et al. (2016) used the integrated wind-erosion modelling system (IWEMS) to simulate dust emissions in northern China (including Xinjiang Province) over the last 30 years and found the dust emissions decreased at the regional scale. However, their simulations were restricted to spring. Zhang et al. (2019) reported that dust emissions in northern China have been declining over recent decades, based on simulations using the Revised Wind Erosion Equation Model (RWEQ). In contrast, an increase in sand and dust emissions in the basin has been reported by Du et al. (2018) under more recent climate scenarios based on the simulation of IWEMS.

The Wind Erosion Prediction System (WEPS) was developed by the USDA Agricultural Research Service to specifically assess soil wind erosion from agricultural lands based on temporal changes in surface parameters (Wagner 2013). The WEPS is a continuous, daily time-step and process-based model that simulates wind erosion of agricultural lands on the basis of seven submodels. These submodels include Soil, Crop, Hydrology, Residue Decomposition, Management, Weather, and Erosion (USDA ARS 2020). Prior to the Erosion submodel calculating soil loss and deposition, the other six submodels simulate changes in agricultural land characteristics. These characteristics provide the necessary parameters required by the Erosion submodel. The Erosion submodel is initiated when the wind speed exceeds the threshold speed for the simulated soil and biomass condition. WEPS model simulates spatial and temporal variability of field conditions and related soil loss/deposition within a field. In addition, the WEPS is the only model to simulate process-based PM10 emissions from agricultural land. The WEPS has been used to assess wind erosion risk for single wind events or discrete wind periods (Hagen 2004; Funk et al. 2004), continuous high wind events (Feng and Sharratt 2009), single year (Chen et al. 2014), and future climate scenarios (Sharratt et al. 2015).
The WEPS was developed according to crop, soil, and weather conditions of the United States. As such, the WEPS utilizes databases developed in the United States. Few crop, soil, and weather databases exist outside the United States, limiting the application of WEPS at a regional scale in China (Pi et al. 2019). Using measured data from other countries or simulated data from other models and regions to expand the initial WEPS databases and thus applying the WEPS outside the United States is an important progress to extend the model (Wagner 2013).

We are not aware of any studies that have quantified the long-term continuous soil loss and PM10 emissions from agricultural lands in the Junggar Basin of northwest China. Human activities such as tillage and irrigation may accelerate or decelerate wind erosion intensity and influence wind erosion risk in terms of air pollution and land degradation under climate change scenario. The objective of this study was therefore to assess the temporal and spatial variability in windblown soil loss and PM10 emissions from agricultural lands in response to climate during the past six decades for locations throughout the Junggar Basin of northwest China.

\section{Materials and Methods}

Climate and weather are necessary data required to drive wind erosion models (Skidmore 1986). Climate and weather data were collected for 11 meteorological stations in Junggar Basin of north Xinjiang from 1958 to 2018 based upon observations taken by China Meteorological Data Network (CMDN) (http://data.cma.cn/site/index. html) (figure 1 and table 1). Although the network acquires data from 37 automated weather stations located in the basin, the 11 meteorological stations featured in this study were chosen based on continuity of weather and climate data over the six last decades as well as soil and crop types corresponding with the WEPS soil and crop databases. Due to the desert environment of the basin, human activity relies greatly on snow/glacier meltwater from these mountains; as a result, agricultural land is distributed along the narrow plain between mountains and desert (Cheng et al. 2009). All the meteorological stations are distributed within the narrow low-altitude plain except for Mulei, where the topography is a mid-altitude plain (figure 1 and table 1). These meteorological stations 
Figure 1

Geomorphic features of Junggar Basin in north Xinjiang and locations of the 11 selected meteorological stations. Station symbols are provided in table 1.

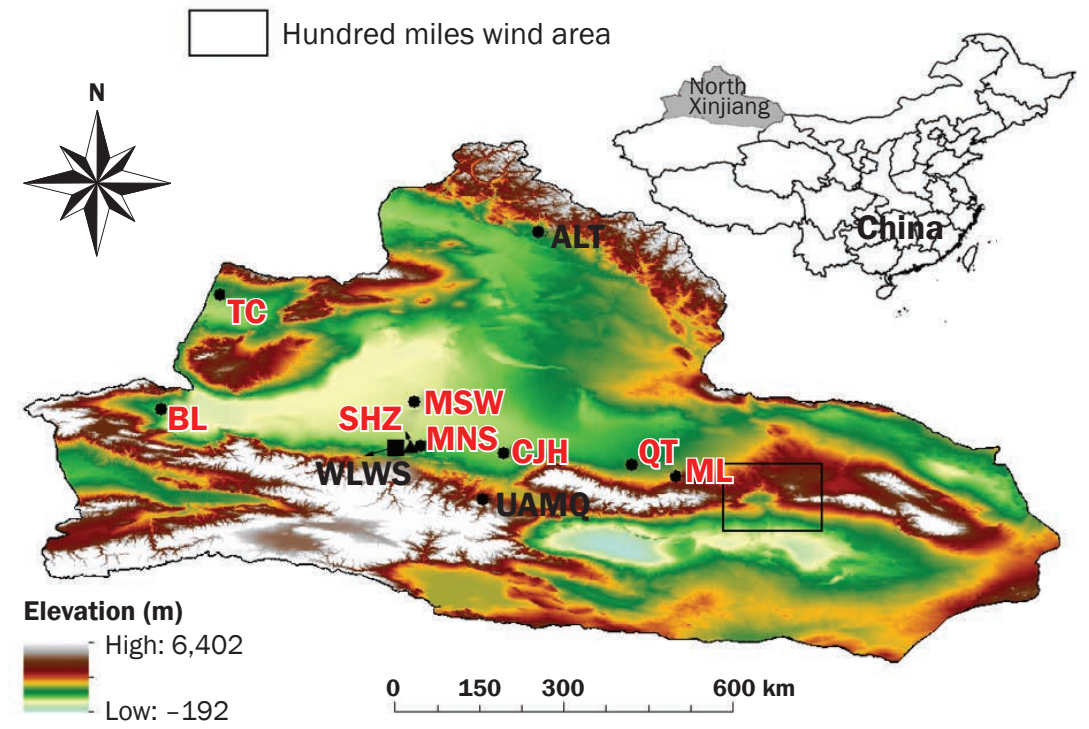

adjacent to or within the plain thus represent the typical climate, crop, and soil characters of agricultural lands in the basin.

Land surface roughness (e.g., crop cover and soil roughness) is one of the most important factors influencing wind erosion because of its essential role in adsorbing momentum from airflow. In the WEPS, absorption of momentum modifies the threshold friction velocity $(u * t)$, friction velocity $(u *)$, and aerodynamic roughness $\left(z_{0}\right)$ (Shao 2008; USDA ARS 2020) of surfaces. Crop types grown in northern Xinjiang Province were downloaded from the Cold and Arid Regions Science Data Center, National Natural Science Foundation of China (http://westdc.westgis.ac.cn) (figure 2a).

Soil type is another essential factor influencing soil wind erosion in WEPS as a result of its role in determining soil roughness, crust, and aggregate properties. In addition, soil type influences the amount of soil particles potentially available for emissions.

Table 1

Geographic location, soil type, and land use characteristics of 11 meteorological stations across the Junggar Basin of Xinjiang Province.

\begin{tabular}{|c|c|c|c|c|c|c|c|c|c|c|c|}
\hline \multirow[b]{2}{*}{ Characteristic } & \multicolumn{11}{|c|}{ Meteorological station } \\
\hline & $\begin{array}{l}\text { Aletai } \\
\text { (ALT) }\end{array}$ & $\begin{array}{l}\text { Bole } \\
(\mathrm{BL}) \\
\end{array}$ & $\begin{array}{l}\text { Caijiahu } \\
\text { (CJH) }\end{array}$ & $\begin{array}{l}\text { Tacheng } \\
\text { (TC) }\end{array}$ & $\begin{array}{l}\text { Manasi } \\
\text { (MNS) }\end{array}$ & $\begin{array}{l}\text { Mosuowan } \\
\text { (MSW) }\end{array}$ & $\begin{array}{l}\text { Mulei } \\
\text { (ML) }\end{array}$ & $\begin{array}{l}\text { Qitai } \\
\text { (QT) }\end{array}$ & $\begin{array}{l}\text { Shihezi } \\
\text { (SHZ) }\end{array}$ & $\begin{array}{l}\text { Urumqi } \\
\text { (URMQ) }\end{array}$ & $\begin{array}{l}\text { Wulanwusu } \\
\text { (WLWS) }\end{array}$ \\
\hline Latitude $\left({ }^{\circ} \mathrm{N}\right)$ & $47^{\circ} 44^{\prime}$ & $44^{\circ} 54^{\prime}$ & $44^{\circ} 12^{\prime}$ & $46^{\circ} 44^{\prime}$ & $44^{\circ} 19^{\prime}$ & $45^{\circ} 01^{\prime}$ & $43^{\circ} 50^{\prime}$ & $44^{\circ} 01^{\prime}$ & $44^{\circ} 19^{\prime}$ & $43^{\circ} 47^{\prime}$ & $44^{\circ} 17^{\prime}$ \\
\hline Elevation (m) & 737 & 533 & 441 & 536 & 315 & 347 & 1,272 & 794 & 444 & 936 & 469 \\
\hline Soil type & Meadow & Humus & Humus & Calcimorphic & Humus & Saline & $\begin{array}{l}\text { Calcimorphic } \\
\text { +stony }\end{array}$ & Fluvo-aquic & Desert & Calcimorphic & Desert \\
\hline $\begin{array}{l}\text { USDA soil } \\
\text { classification* }\end{array}$ & $\begin{array}{l}\text { Sandy } \\
\text { loam }\end{array}$ & $\begin{array}{l}\text { Loamy } \\
\text { sand }\end{array}$ & $\begin{array}{l}\text { Loamy } \\
\text { sand }\end{array}$ & $\begin{array}{l}\text { Sandy } \\
\text { loam }\end{array}$ & $\begin{array}{l}\text { Loamy } \\
\text { sand }\end{array}$ & $\begin{array}{l}\text { Loamy } \\
\text { sand }\end{array}$ & $\begin{array}{l}\text { Loamy } \\
\text { sand }\end{array}$ & $\begin{array}{l}\text { Sandy } \\
\text { clay loam }\end{array}$ & Sand & $\begin{array}{l}\text { Sandy } \\
\text { loam }\end{array}$ & Sand \\
\hline Land use type & Wheat & Cotton & Cotton & Wheat & Cotton & Cotton & Cotton & Cotton & Cotton & Cotton & Cotton \\
\hline $\begin{array}{l}\text { Geomorphic } \\
\text { features }\end{array}$ & $\begin{array}{l}\text { Low- } \\
\text { altitude } \\
\text { plain }\end{array}$ & $\begin{array}{l}\text { Low- } \\
\text { altitude } \\
\text { plain }\end{array}$ & $\begin{array}{l}\text { Low- } \\
\text { altitude } \\
\text { plain }\end{array}$ & $\begin{array}{l}\text { Low- } \\
\text { altitude } \\
\text { plain }\end{array}$ & $\begin{array}{l}\text { Low- } \\
\text { altitude } \\
\text { plain }\end{array}$ & $\begin{array}{l}\text { Low- } \\
\text { altitude } \\
\text { plain }\end{array}$ & $\begin{array}{l}\text { Mid- } \\
\text { altitude } \\
\text { plain }\end{array}$ & $\begin{array}{l}\text { Low- } \\
\text { altitude } \\
\text { plain }\end{array}$ & $\begin{array}{l}\text { Low- } \\
\text { altitude } \\
\text { plain }\end{array}$ & $\begin{array}{l}\text { Low- } \\
\text { altitude } \\
\text { plain }\end{array}$ & $\begin{array}{l}\text { Low- } \\
\text { altitude } \\
\text { plain }\end{array}$ \\
\hline $\begin{array}{l}\text { Silt }\left(\mathrm{g} \mathrm{g}^{-1}\right)(0.002 \\
\text { to } 0.05 \mathrm{~mm})\end{array}$ & 0.064 & 0.112 & 0.112 & 0.257 & 0.112 & 0.070 & 0.048 & 0.194 & 0.024 & 0.257 & 0.024 \\
\hline $\begin{array}{l}\text { Clay }\left(\mathrm{g} \mathrm{g}^{-1}\right) \\
(<0.002 \mathrm{~mm})\end{array}$ & 0.082 & 0 & 0 & 0.135 & 0 & 0.034 & 0.034 & 0.255 & 0.039 & 0.135 & 0.039 \\
\hline $\begin{array}{l}\text { Suspension } \\
\text { fraction }\left(\mathrm{g} \mathrm{g}^{-1}\right) \\
(<0.1 \mathrm{~mm}) \dagger\end{array}$ & 0.483 & 0.57 & 0.57 & 0.83 & 0.57 & 0.525 & 0.52 & 0.643 & 0.81 & 0.83 & 0.81 \\
\hline
\end{tabular}


Figure 2

(a) Land use type and annual mean loss of soil loss, and (b) soil type and annual mean PM10 emissions from 1958 to 2018 across 11 meteorological stations within the Junggar Basin of north Xinjiang. Station symbols are provided in table 1.

(a)

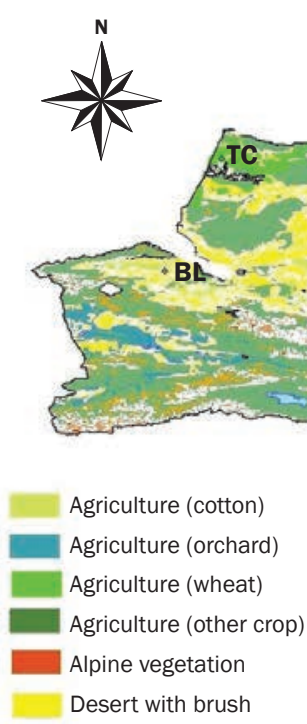

Mean annual simulated soil loss $\left(\mathrm{kg} \mathrm{m}^{-2}\right)$

- 0.02 to 9.03

- 9.04 to 22.62

- 22.63 to 41.49

41.50 to 98.36

98.37 to 105.05

105.06 to 138.44

138.45 to 344.47
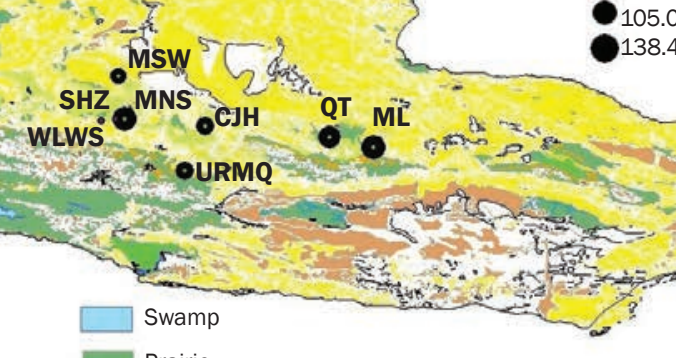

(b)

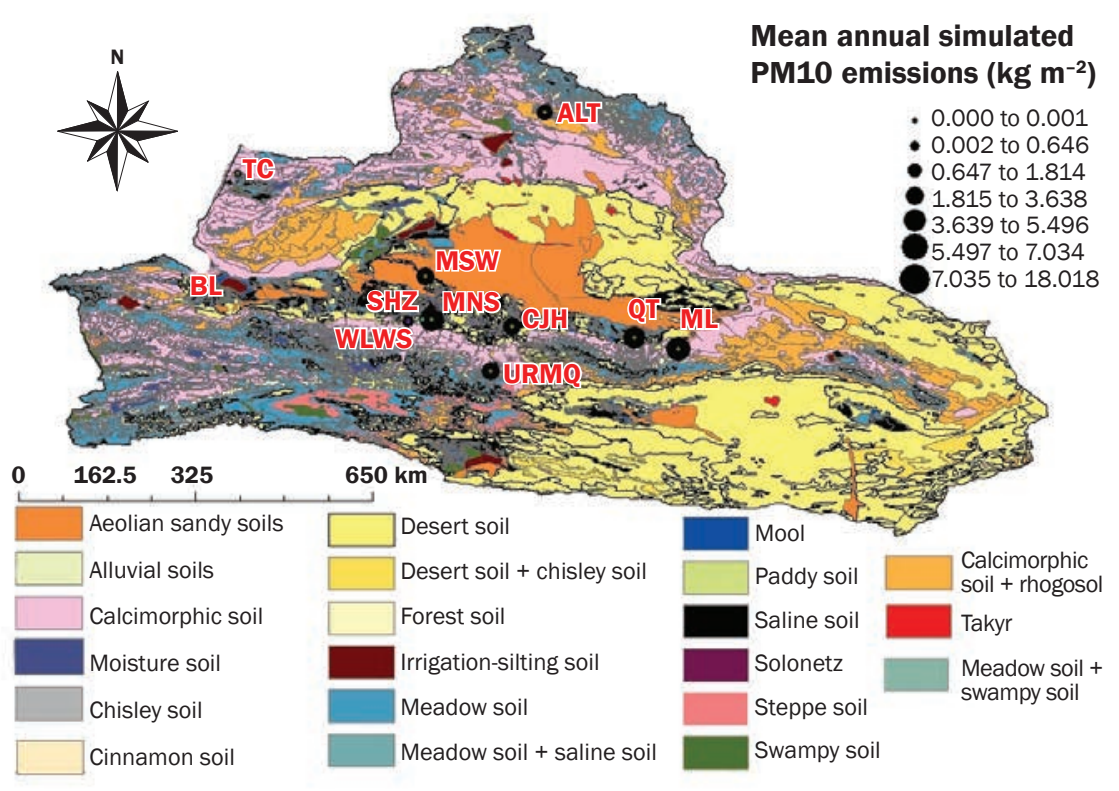

For example, soil particles $<2 \mathrm{~mm}$ are the component potentially available for immediate erosion, and soil particles $>2 \mathrm{~mm}$ are nonerodible (USDA ARS 2020). The WEPS defines wind erosion processes according to the transport of soil particles by creep $(0.84$ to $2.0 \mathrm{~mm}$ ), saltation ( 0.1 to $0.84 \mathrm{~mm})$, suspension $(<0.1 \mathrm{~mm})$, and PM10 $(<0.01 \mathrm{~mm})$. Soil types were downloaded from the Cold and Arid Regions Science Data Center, National Natural Science Foundation of
China (figure 2b). These seven soils represent $45 \%$ of the area of the basin.

Climate and Weather Inputs. The WEPS model requires climate and weather inputs, including monthly and daily average maximum and minimum temperature $\left({ }^{\circ} \mathrm{C}\right)$, solar radiation (Langleys $\mathrm{d}^{-1}$ ), dew point temperature $\left({ }^{\circ} \mathrm{C}\right)$, and daily precipitation $(\mathrm{mm})$, and the corresponding peak intensity $\left(\mathrm{mm} \mathrm{h}^{-1}\right)$, duration (h), and time to peak (h) in precipitation, as well as hourly wind data. The
CMDN monitors maximum and minimum temperature, daily precipitation, and maximum hourly precipitation at $2 \mathrm{~m}$ height (Peng et al. 2019), but not solar radiation, dew point temperature, precipitation intensity, duration, and time to peak.

Solar radiation influences evapotranspiration and plant productivity, thus potentially impacting soil and soil surface properties. Solar radiation was estimated by an empirical linear relationship between solar radiation and measured sunshine duration as reported by Chen et al. (2005) in Xinjiang Province. Dew point temperature was calculated from the measured temperature and relative humidity using the method of Lawrence (2005). Precipitation duration (h) was estimated by dividing daily precipitation $(\mathrm{mm})$ by hourly mean precipitation $\left(\mathrm{mm} \mathrm{h}^{-1}\right)$, which was estimated based on maximum and minimum hourly precipitation $(\mathrm{mm}$ $\mathrm{h}^{-1}$ ). The time to peak precipitation intensity was assumed to occur halfway through the precipitation event (half of the precipitation duration). These methods were previously used to estimate precipitation duration and time to peak by Pi et al. (2019). Pi et al. (2019) found that WEPS was insensitive to precipitation duration and time to peak precipitation as a $60 \%$ change in time of peak intensity resulted in $<1 \%$ change in soil loss by wind erosion in a desert environment because precipitation is rare. Precipitation duration and time to peak precipitation are highly sensitive parameters to soil water erosion in the Water Erosion Prediction Project (WEPP) model (Nearing et al. 1990), but not in the WEPS (Feng and Sharratt 2005).

The wind inputs required by WEPS includes hourly wind speed and daily wind direction at a height of $10 \mathrm{~m}$. However, hourly wind speed was not continuous from 1958 to 2018. Missing hourly wind speed was estimated using the WEPS weather submodel and measured daily average wind speed and average maximum wind speed at $10 \mathrm{~m}$ height (equation 1 ):

$$
\begin{aligned}
& \mathrm{U}(\mathrm{I})=\left(\mathrm{u}_{\max }+\mathrm{u}_{\text {min }}\right) / 2+0.5 \times\left(\mathrm{u}_{\text {max }}\right. \\
& \left.-\mathrm{u}_{\text {min }}\right) \times \cos \left[2 \pi\left(24-\mathrm{hr}_{\text {max }}+\mathrm{I}\right) / 24\right],
\end{aligned}
$$

where $U(I)$ is wind speed $\left(\mathrm{m} \mathrm{s}^{-1}\right)$ for the Ith hour of the day, $u_{\max }$ and $u_{\min }$ are daily maximum and minimum wind speed $\left(\mathrm{m} \mathrm{s}^{-1}\right)$, and $\mathrm{hr}_{\max }$ is the hour of the day when wind speed is maximum (USDA ARS 2020). Wind speeds are generally close to a Weibull dis- 
Table 2

Time series trends in the annual precipitation, solar radiation, average air temperature, average relative humidity, average wind speed, simulated soil loss, and PM10 emission from 1958 to 2018 in the Junggar Basin.

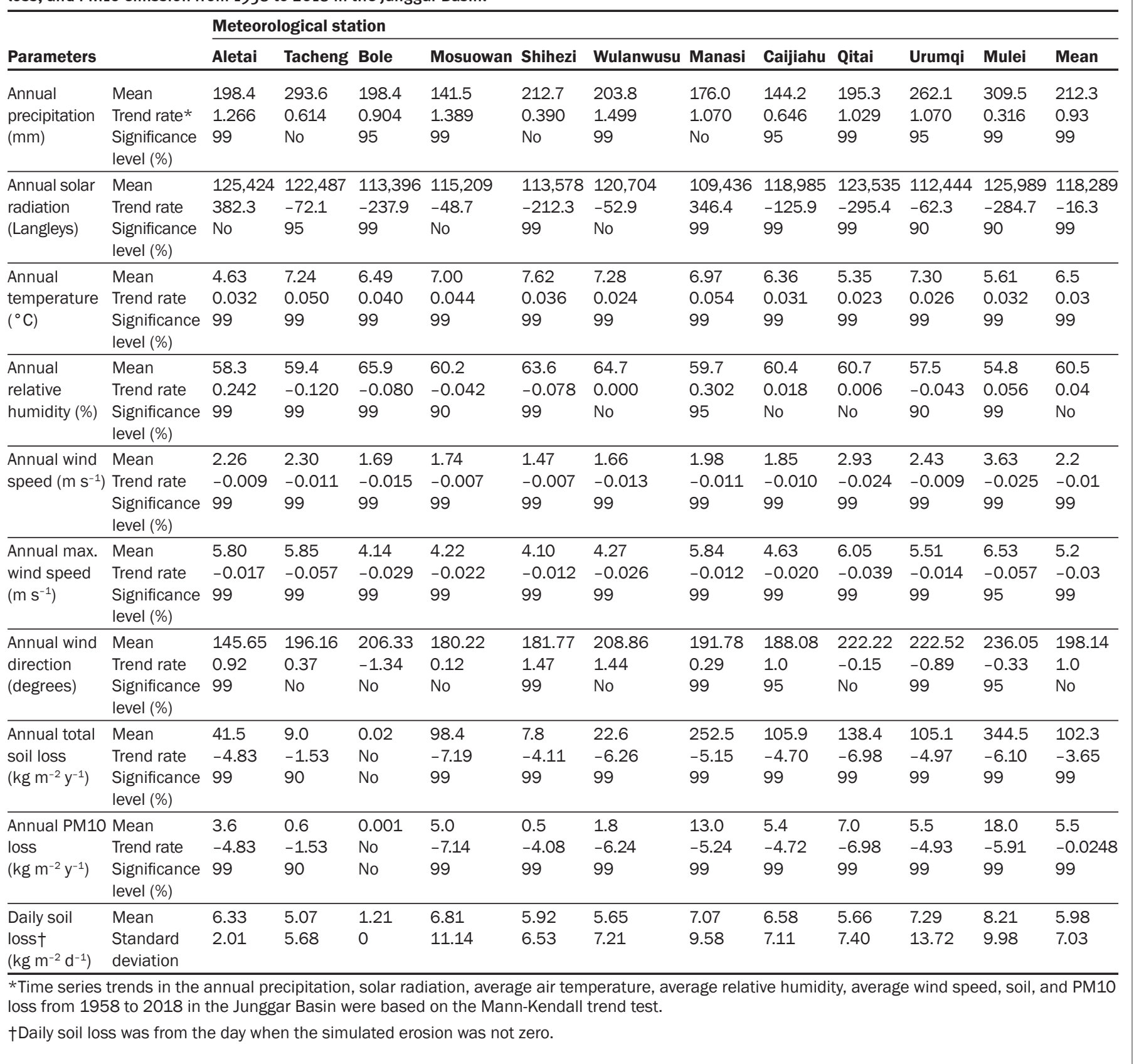

tribution with time (Skidmore and Tatarko 1990). Since $\mathrm{hr}_{\max }$ and $\mathrm{u}_{\min }$ were not available for any station, we assumed $\mathrm{hr}_{\text {max }}$ was 12 and the daily $\mathrm{u}_{\min }$ was $0 \mathrm{~m} \mathrm{~s}^{-1}$ (USDA ARS 2020). The WEPS erosion submodel is initiated when the wind speed exceeds the threshold speed. The WEPS assumes the minimum threshold wind speed to be $5 \mathrm{~m}$ $\mathrm{s}^{-1}$ at a height of $10 \mathrm{~m}$. When the maximum or average wind speed exceeded $5 \mathrm{~m} \mathrm{~s}^{-1}$, the model begins to simulate erosion (USDA ARS 2020).

Threshold wind speed in WEPS is a dynamic parameter, with adjustments above this minimum threshold made as a result of changing plant, crust, and soil aggregate properties over time. The Junggar Basin is dominated by westerly winds (Pi et al. 2014), which originate from gaps in the mountains located northwest of the basin. These gaps in the mountains allow intrusion of con- tinental air masses (westerly winds) to the Junggar Basin (Pi et al. 2017b; Dong et al. 2000). However, the Tianshan Mountains located south of the Junggar Basin constrain atmospheric circulation within the basin and result in southwesterly winds at selected weather stations (table 2).

Soil, Crop, and Management Inputs. The soil, crop types, and corresponding agricultural management practices at the selected meteorological stations must match the 
WEPS soil and crop databases when simulating wind erosion. The WEPS soil and crop submodels use the WEPS soil and crop databases to estimate changes in soil wind erodibility and plant growth, both of which directly influence wind erosion parameters such as the soil particle size distribution, organic matter, and crop leaf and stem area index and height (USDA ARS 2020). The WEPS databases include files for over 1,000 soil types and 111 crop management practices. For each crop type, WEPS crop management practices provide a series of field practices such as seeding, tillage, break crust, or flatten standing biomass and bury flat biomass (USDA ARS 2020). For this study, default WEPS files were selected according to characteristic soil and crop types at each of the 11 stations (table 1). There were six observed soil types and two crop types (wheat [Tritcum aestivum L.] and cotton [Gossypium hirsutum L.]) that corresponded with the WEPS soil and crop databases across the 11 stations. Cotton is a very common crop in north Xinjiang. Cotton production in Xinjiang accounts for $54 \%$ of the total in China (Li et al. 2020a). The Junggar Basin is characterized by a desert environment; most of the agricultural fields are irrigated. However, no irrigation regime could be referred at the 11 stations. Based on several interviews to examine farmers' irrigation decisions with respect to their choice of irrigation regime, amount, and time, we subjectively used three irrigations $(51 \mathrm{~mm}$, Border, Furrow) before and after seeding in these crop management practices. Crop row direction was subjectively considered to be 0 degrees based on several fields' observations.

Confidence in using WEPS to Simulate Soil Loss and PM10 Emissions. The lack of long-term continuous observations of soil loss and PM10 emissions has precluded validating and improving wind erosion models, particularly in Asian dust source regions (Shao and Dong 2006; Shao 2008; Pi et al. 2019). Measuring long-term wind erosion is generally costly and time consuming (Raei et al. 2021). We are not aware of any longterm wind erosion measurements in north Xinjiang Province. In addition, there is limited data available on dust concentrations in Xinjiang Province for model validation (Shao and Dong 2006). To overcome this limitation, we used dust event frequency at meteorological stations to associate the simulated soil loss and PM10 emission, although the comparison was limited. Based on observed visibility, dust events were divided into floating dust $(<10 \mathrm{~km})$, blowing dust $(0.1$ to $10 \mathrm{~km})$, and dust storm $(<0.1 \mathrm{~km})$ (Pi et al. 2017b). Dust frequencies and associated dust visibilities and concentrations are strongly related to soil wind erosion, because dust emissions due to wind erosion contributed most of the dust concentrations. Dust event data were obtained from the National Climatic Centre of China, China Meteorological Administration (http://data. cma.cn/site/index.html).

Dust climatology in terms of dust storm frequency and seasonal variations in Xinjiang Province have been described by Piet al. (2017a). For this study, we simulated annual soil loss and PM10 emissions each year at 11 meteorological stations from 1958 to 2018 because those stations represented the longterm average in number of dust storms across the region. Our long-term simulation of soil loss and PM10 emissions sought to provide insights to annual dust emissions that might be expected for various crop and soil types in north Xinjiang.

Statistical Analysis and Model Validation. The Mann-Kendall trend test was used to examine whether time series trends have a monotonic upward or downward trend in meteorological parameters, simulated soil loss, and PM10 emissions from 1958 to 2018. Trends were based on averages of simulated soil loss, measured precipitation, and wind speed across all stations within a region. The application of the test requires the elements of a time series $\left(\mathrm{x}_{1}, \mathrm{x}_{2}, \mathrm{x}_{3}, \ldots, \mathrm{x}_{n}\right)$ be replaced by their ranks $\left(\mathrm{R}_{1}, \mathrm{R}_{2}, \mathrm{R}_{3}, \ldots, \mathrm{R}_{n}\right)$. The time series is evaluated using test statistic $\mathrm{S}$, which is expressed as equation 2 :

$\mathrm{S}=\sum_{i=1}^{n-1} \sum_{j=\mathrm{i}+1}^{n} \operatorname{sgn}\left(x_{j}-x_{i}\right)$,

where

$$
\operatorname{sgn}\left(x_{j}-x_{i}\right)=\left\{\begin{array}{rl}
+1 & \text { if }\left(x_{j}-x_{i}\right)>0 \\
0 & \text { if }\left(x_{j}-x_{i}\right)=0 \\
-1 & \text { if }\left(x_{j}-x_{i}\right)<0
\end{array},\right.
$$

where sgn is the sign function or signum function. A negative $S$ indicates a negative trend in the time series and a positive $\mathrm{S}$ indicates a positive trend in the time series. The test statistic $\mathrm{S}$ is assumed to be normally distributed with a mean zero and variance $(\operatorname{Var}[\mathrm{s}])$ equal to $n(n-1)(2 n+5) / 18$ (Hamed 2008). The standard normal variate $Z$ was used to assess the significance of the time series according to equation 4 :

$\mathrm{Z}= \begin{cases}\frac{s-1}{\sqrt{\operatorname{Var}(s)}} & s>0 \\ 0 & s=0 \\ \frac{s+1}{\sqrt{\operatorname{Var}(s)}} & s<0\end{cases}$

Regression analysis was also used to set up the relationship between simulated erosion and meteorological parameter to examine how climate-change can influence land degradation and soil wind erosion. Regression analysis also was used to examine the relationship between simulated erosion and frequency of dust events to assess these simulated results.

\section{Results and Discussion}

Spatial Distribution and Temporal Trends of Meteorological Parameters. Significant monotonic upward or downward trends (figure 3) were found in all major meteorological parameters across stations as the time series trend at the $99 \%$ level of confidence based on the Mann-Kendall nonparametric test except annual average relative humidity (table 2). The trends in annual precipitation and average temperature indicated an increase of $0.93 \mathrm{~mm} \mathrm{y}^{-1}$ and $0.03^{\circ} \mathrm{C} \mathrm{y}^{-1}$, respectively, from 1958 to 2018 . The trends in annual solar radiation, average wind speed, and average maximum wind speed at $10 \mathrm{~m}$ height appeared to decrease at 16.3 $\mathrm{Lang}^{-1}$, $0.01 \mathrm{~m} \mathrm{~s}^{-1} \mathrm{y}^{-1}$, and $0.03 \mathrm{~m} \mathrm{~s}^{-1} \mathrm{y}^{-1}$, respectively (table 2), over the six decades. The significant trends we found in most meteorological parameters indicated that northern Xinjiang Province has undergone an "unequivocal" change in climate (IPCC 2007; Scott et al. 2016; Fu et al. 2013; Deng et al. 2015), and appeared to synchronize with global-scale climate signal as reported by Wu et al. (2010). Weakening of the Arctic oscillation (AO) and Siberian High may relate to the weak wind activities of the basin (Shao et al. 2013).

The Aletai station in northern Junggar Basin is relatively cool and wet as it has the lowest annual average temperature and relatively high annual precipitation and average relative humidity as compared with other stations in southern Junggar Basin (e.g., Manasi station). This may be due to moist and cold air masses intruding the basin from the northwest (Huang et al. 2017). These moist and cold air masses are gradually depleted of moisture when they pass through the Gurbantunggut Desert. 


\section{Figure 3}

(a) Time series of annual mean loss of soil from 1958 to 2018 at all the stations of Junggar Basin except Mulei, and (b) annual mean soil loss and wind speed at Mulei from 1958 to 2018.

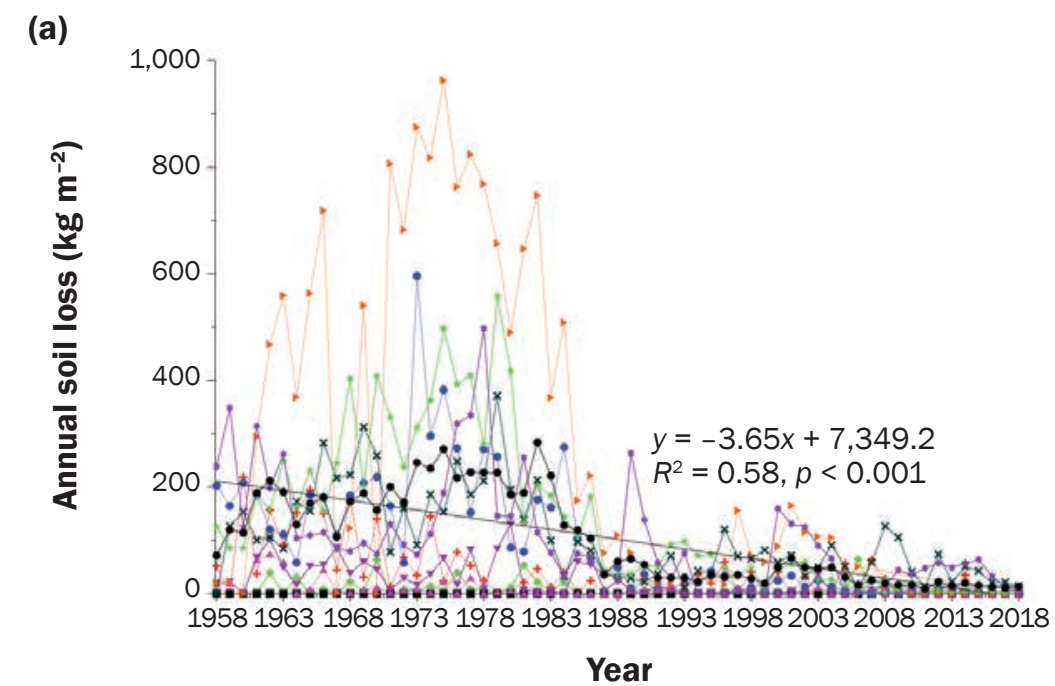

\section{Legend}

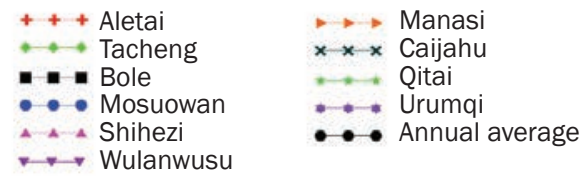

(b)

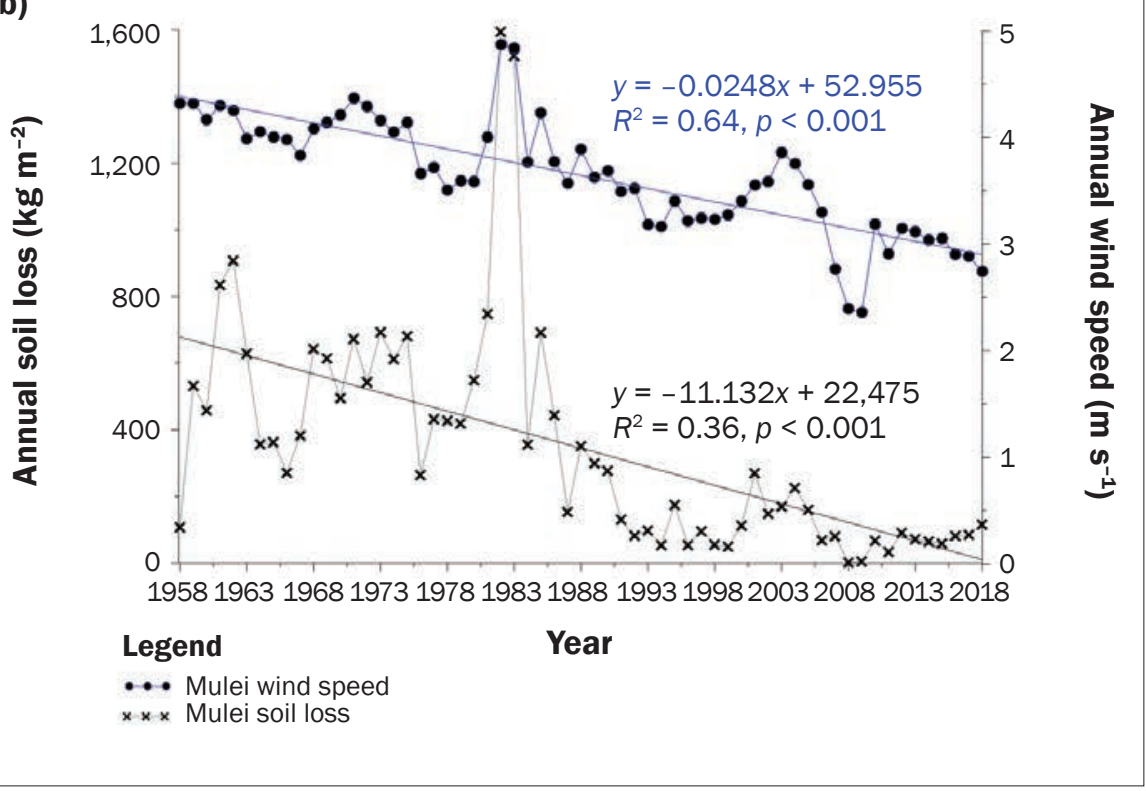

South Junggar Basin is relatively warm and dry, but temperature, precipitation, and humidity varied among adjacent stations. For example, Mosowan has the lowest annual precipitation with an average of $141.5 \mathrm{~mm}$ $\mathrm{y}^{-1}$, which was half that at Urumqi. However, Mosowan was only $180 \mathrm{~km}$ northwest of Urumqi. The greater variation of climatic conditions among adjacent stations has been due to the varied topography and elevation (Pi et al. 2017b). Snowfall and snowmelt dominate the hydrological process of southern Junggar Basin (Guo and Li 2015). Urumqi, for example, which is in close proximity to the Tian Shan Mountains, may have a relatively wet climate and plentiful water sources to support dense vegetation. The Mosowan station, in contrast, is located further away from the Tian Shan Mountains (adjacent to the Gurbantunggut Desert) and thus is characterized by a dry environment.

Temporal Trends of Soil Loss and PM10 Emissions. Our simulations show that soil loss and PM10 emissions decreased from 1958 to 2018 across stations in the Junggar Basin. The time series trends of mean soil loss and PM10 emission were significant at the 95\% confidence level based on the Mann-Kendall nonparametric trend tests. The trends in mean annual total soil loss and PM10 emission indicated a decrease of 3.65 and $0.20 \mathrm{~kg}$ $\mathrm{m}^{-2} \mathrm{y}^{-1}$, respectively (table 2 and figure $3 \mathrm{a}$ ), over the six decades. The time series trend was negative at the $90 \%$ confidence level for all the 11 stations except at Bole, where simulated soil loss only occurred in 2008 with a value of $1.20 \mathrm{~kg} \mathrm{~m}^{-2}$ (figure $3 \mathrm{a}$ ). In all other years, no soil loss or PM10 emission was simulated at the Bole station. This can be due to the lower annual average maximum wind speed $\left(4.14 \mathrm{~m} \mathrm{~s}^{-1}\right.$, second smallest in all the stations) and greater annual average relative humidity (65.9\%, greatest of all the stations). The relative humidity is a factor suppressing wind erosion (Mckenna Neuman 2003). The relative humidity appeared to influence simulated wind erosion at the semiarid study sites based on a greater coefficient of regression (table 3), although not statistically significant (discussed in the next section). This finding is consistent with previous research in which decreasing dust activities has been detected in northern China (Song et al. 2016; Zhang et al. 2019).

Wind erosion was frequent and severe in April and May during which the average simulated soil losses were 19.0 and $21.7 \mathrm{~kg} \mathrm{~m}^{-2}$, respectively (figure 4). This is not surprising because April and May had greater average wind speed and lower relative humidity and maximum wind speed as compared with other months (figure 4). Spring has been considered the season with the most frequent dust storms in northern China (Zhou and Zhang 2003). The WEPS model simulated no erosion at any station in December, January, and February, due to weak winds, low temperatures, and considerable precipitation (figure 4), the latter two of which resulted in snow cover and frozen topsoils unavailable for emissions (USDA ARS 2020)—evidence that the average temperatures in December, January, and February were $<-8.6^{\circ} \mathrm{C}$. However, these results appear to contrast with $\mathrm{Li}$ et al. (2020b), in which 
Table 3

Regression of soil loss and PM10 emission versus various meteorological parameters from 1958 to 2018 in the Junggar Basin.

\begin{tabular}{|c|c|c|}
\hline \multirow[b]{2}{*}{ Meteorological parameters } & \multicolumn{2}{|l|}{ Regression model* } \\
\hline & Soil loss $\left(\mathrm{kg} \mathrm{m}^{-2}\right)$ & PM10 emission $\left(\mathrm{kg} \mathrm{m}^{-2}\right)$ \\
\hline Annual precipitation $(\mathrm{mm})$ & $y=0.461 x, R^{2}=0.48, P=0.0001 \dagger$ & $y=-0.0248 x, R^{2}=0.48, P=0.001$ \\
\hline Annual average temperature $\left({ }^{\circ} \mathrm{C}\right)$ & $y=16.0 x, R^{2}=0.53, P=0.007$ & $y=0.86 x, R^{2}=0.53, P=0.005$ \\
\hline Annual average relative humidity (\%) & $y=1.842 x, R^{2}=0.59, P=0.609$ & $y=0.099 x, R^{2}=0.59, P=0.587$ \\
\hline Annual average wind speed $\left(\mathrm{m} \mathrm{s}^{-1}\right)$ & $y=49.2 x, R^{2}=0.70, P=0.0001$ & $y=2.646 x, R^{2}=0.70, P=0.0001$ \\
\hline Annual average wind direction (degrees) & $y=0.632 x, R^{2}=0.59, P=0.0001$ & $y=0.034 x, R^{2}=0.60, P=0.0001$ \\
\hline
\end{tabular}

*Regression model: $y$ is value of the soil loss and PM10 emission $\left(\mathrm{kg} \mathrm{m}^{-2}\right), x$ is value of a meteorological parameters.

$\dagger P$ value $<0.05$ means that $y$ is significantly associated with $x$ at the $95 \%$ confidence level.

\section{Figure 4}

Monthly meteorological parameters and simulated monthly soil loss and PM10 emissions averaged across 11 meteorological stations in Junggar Basin of north Xinjiang.

(a)

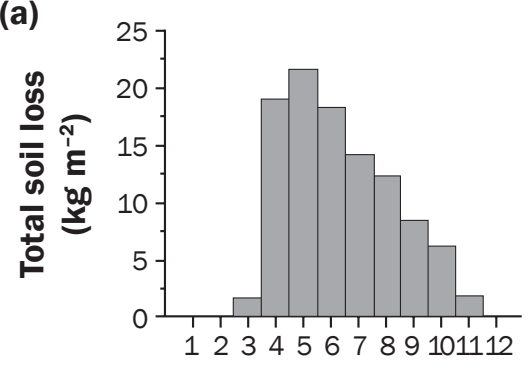

(d)

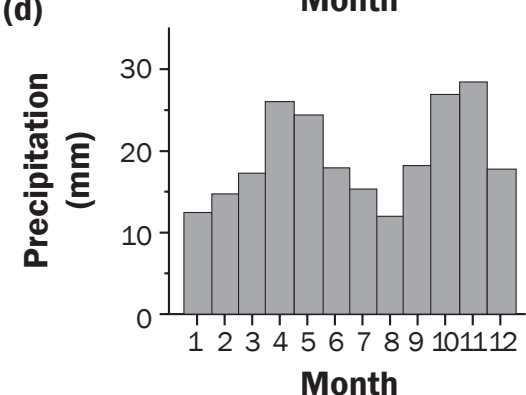

(g)

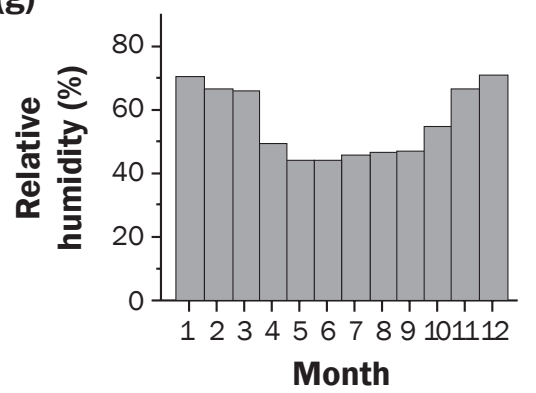

(b)

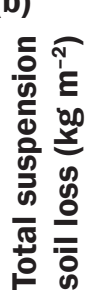

(e)

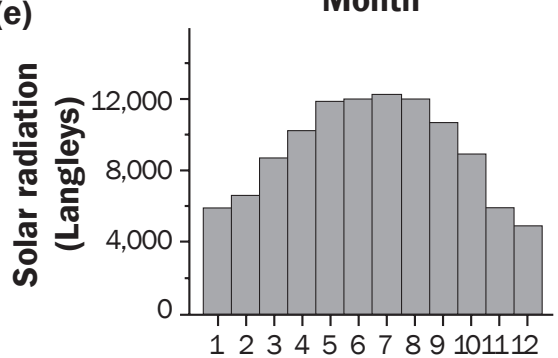

(h)

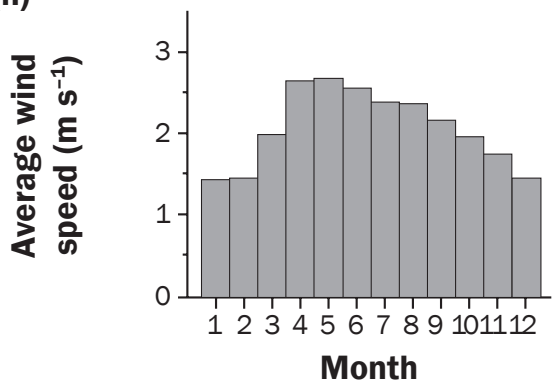

(c)

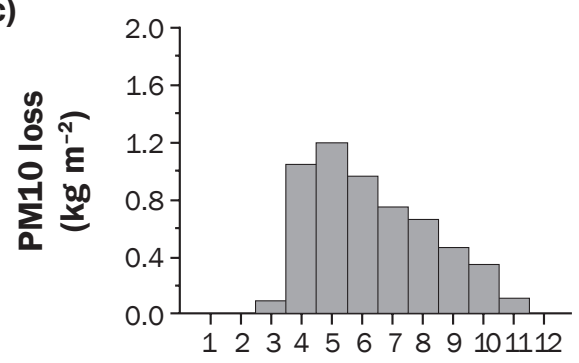

(f)

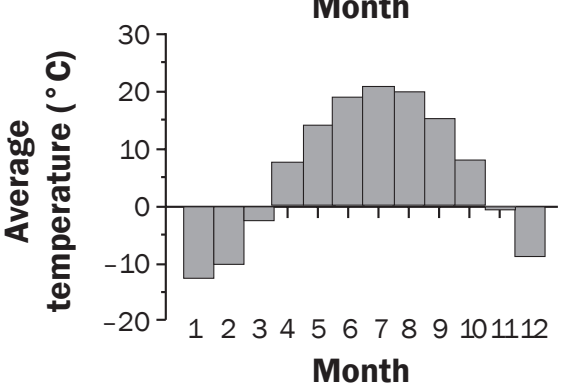

(i)

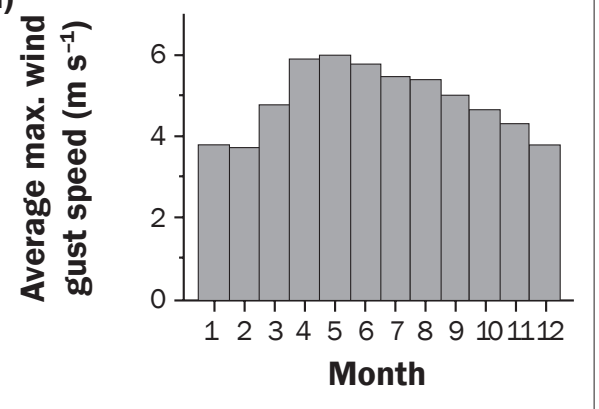

they simulated greater soil loss in winter (December, January, and February) from 1986 to 2099 in Central Asia, using the RWEQ in northern Xinjiang Province, but this is not surprising because RWEQ fails to consider changes in soil conditions associated with freezing (Fryrear et al. 1998). Previous studies have reported frequent wind erosion events in northwestern China during spring (Shao and Wang 2003; Pi et al. 2014,
2016; Zheng et al. 2016; Song et al. 2016), but we are not aware of any studies that have observed wind erosion events during winter in the region. 
Spatial Distribution of Soil Loss and PM10 Emissions. The highest single year soil loss and PM10 emissions occurred at Mulei in 1982. Cotton was grown on a Calcimorphic soil in 1982 at this station (figure 2a), and simulated total soil loss and PM10 emission at this station in 1982 reached 1,594.5 and $86.6 \mathrm{~kg} \mathrm{~m}^{-2}$, respectively. This soil loss and PM10 emission was greater than the total loss of soil and PM10 emissions at Tacheng (541.7 and $38.3 \mathrm{~kg} \mathrm{~m}^{-2}$ ), Bole (1.2 and 0.1 $\mathrm{kg} \mathrm{m}^{-2}$ ), Shihezi $\left(470.1\right.$ and $32.4 \mathrm{~kg} \mathrm{~m}^{-2}$ ), and Wulanwusu $\left(1,357.1\right.$ and $\left.108.8 \mathrm{~kg} \mathrm{~m}^{-2}\right)$ over the past six decades. The average wind speed and average maximum wind speed at $10 \mathrm{~m}$ height at Mulei in 1982 reached 4.87 and $5.92 \mathrm{~m} \mathrm{~s}^{-1}$, respectively, which were greater than that in any other years, at other sites. The highest loss of soil and PM10 emission thus appeared to correspond with the greatest wind energy.

The WEPS simulated no annual erosion at least once at all the 11 weather stations except Mulei (figure 3). For example, there was no simulated erosion in 2006 and 2017 at Qitai although the mean annual soil loss reached $138.4 \mathrm{~kg} \mathrm{~m}^{-2} \mathrm{y}^{-1}$ at the site. The lowest soil loss $\left(1.69 \mathrm{~kg} \mathrm{~m}^{-2} \mathrm{y}^{-1}\right)$ at Mulei occurred in 2008. In contrast, there was very limited wind erosion risk at Bole as a result of no simulated erosion during the 60 years except in 2008. In 2008, the simulated total loss of soil and PM10 emission in Bole were 1.2 and $0.1 \mathrm{~kg} \mathrm{~m}^{-2}$, respectively. Despite Mulei appearing to have the highest perennial wind erosion risk and Bole appearing to have the lowest perennial wind erosion risk as compared with any other sites in the basin (table 2), both stations appeared to have the same amount of soil loss in 2008 (figure 3). This indicated that wind erosion risk varied not only among stations, but also years. The highest single year soil loss at Manasi (962.6 $\mathrm{kg} \mathrm{m}^{-2} \mathrm{y}^{-1}$ ) occurred in 1975, whereas soil loss during the same year at Mulei was $681.3 \mathrm{~kg} \mathrm{~m}^{-2} \mathrm{y}^{-1}$. This suggested that the dust hotspot source areas changed considerably from year to year within the basin.

Regression analysis of annual soil loss as a function of annual average wind speed and wind direction had the highest coefficient of determination $\left(R^{2}=0.70\right)$ as compared with relationships between annual soil loss and other major meteorological parameters (table 3). These results indicated that annual soil loss was influenced primarily by the driving force of the wind. The coefficients of determination of the correlation analysis for annual precipitation, solar radiation, average temperature, and relative humidity varied and ranged from 0.48 for precipitation to 0.62 for solar radiation, which suggested there are statistical significances between soil loss and precipitation, solar radiation, temperature, as well as wind direction (table 3). These parameters thus may directly or indirectly impact annual soil loss as a result of influencing the erodibility of sites through the threshold friction velocity and plant and soil surface properties. Higher precipitation and temperature are beneficial to plant productivity at these sites (Sala et al. 1988; Grace 1988), thus potentially increasing the threshold friction velocity and reducing the erosion rate. Wind is the primary factor driving wind erosion, and lower solar radiation is associated with greater soil surface water content (Li et al. 2016). Drier cropland soils typically are more susceptible to erosion due to their lower inter-particle cohesion. Lower solar radiation and wind speed may reverse this effect. The simulated reduction in erosion at all the 11 stations was directly associated with decreasing wind speed and indirectly with increasing annual precipitation and temperature and decreasing solar radiation. A relatively poor relationship $\left(R^{2}\right.$ $=0.48$ ) was found between precipitation and simulated soil loss as compared with other meteorological parameters. This could be due to the impact of irrigation practices, which can suppress wind erosion. Humidity appeared to influence simulated annual wind erosion at the semiarid study sites based on a greater coefficient of regression (table 3), although not statistically significant. This finding is consistent with previous research and highlights the active role of the "warming climate" in restraining wind erosion activities (Song et al. 2016; Zhang et al. 2019).

Wind direction impacts soil wind erosion as a result of influencing aerodynamic roughness. Aerodynamic roughness is also dependent on roughness element configurations such as ridge height and orientation, crop row orientation, and barrier direction (Burri et al. 2011; Webb et al. 2014; USDA ARS 2020). Pi et al. (2020) found crop rows oriented perpendicular to the wind resulted in the smallest soil loss while crop rows oriented parallel to the wind resulted in the greatest soil loss. Prevailing winds were from the southwest for these selected weather stations. As a result, northerly orientation of crop rows and ridges were considered to be effective in reducing soil wind erosion. For example, though the annual total soil loss reached $344.5 \mathrm{~kg} \mathrm{~m}^{-2} \mathrm{y}^{-1}$ at Mulei, soil loss may be more severe if prevailing wind were from $236^{\circ}$ to $180^{\circ}$ (table 2 ). In this study, no barriers were placed along simulated boundaries based on Pi et al. (2019).

As expected, annual soil loss and PM10 emissions were respectively 1.57 and 1.34 times greater from cotton as compared with wheat. Soil erodibility is typically greater for cotton than wheat fields as a result of relatively low plant protection in cotton fields. For example, Pi et al. (2017a) reported that average soil loss was $95.3 \mathrm{~g} \mathrm{~m}^{-2}$ from cotton fields and $31.4 \mathrm{~g} \mathrm{~m}^{-2}$ from wheat fields across two years.

The highest loss of soil and PM10 emission occurred at Mulei. The Mulei station had the greatest annual average and maximum wind speed (table 2). This is not surprising because Mulei was in close proximity to what is regionally known as the "hundred miles wind area" where a gap in the Tian Shan Mountains causes sustained high winds (figure 1). Winds are channeled through the gap in the mountains during passage of synoptic weather systems. The gap physically constricts and constrains the wind, thus generating frequent and greater wind events in the "hundred miles wind area" (Cheng et al. 2015; Wang et al. 2018). Higher dust flux also was measured in the southwest as compared to other regions of the Junggar Basin as well as central and western Inner Mongolia and northwestern Gansu (Song et al. 2016).

The proportion of simulated suspension particles to total soil loss ranged from $82.9 \%$ at Tacheng to $94.3 \%$ at Bole. The high proportion of suspension particles (mean of 91.4\%) simulated by the WEPS model indicated the soil loss in suspension dominates the erosion process on agricultural lands in the study area. In contrast, a relatively lower proportion of suspension particles to total soil loss (mean of $75.8 \%$ ) was found in a desert environment of south Xinjiang (Pi et al. 2017c). This suggested that erosion from agricultural land appeared to have a greater regional air quality risk due to fine suspended particles and a higher risk for land degradation due to loss of fine and fertile soil particles. In contrast, desert typically has coarser sediments and lower suspension contents, thus the erosion of desert environments may pose a smaller risk to air quality, but have 
a greater environmental risk in abrading and burying plants, facilities, or adjacent roadways than agricultural environments.

Comparison of WEPS with Dust Event Frequencies. Comparing model outputs with measured data is a necessary step in the application of wind erosion models for assessing soil loss or dust emissions. However, the lack of long-term continuous soil loss and PM10 emission observations has limited evaluating wind erosion models (Shao 2008; Song et al. 2016; Pi et al.2019). Zheng et al. (2016) measured soil loss from a cotton field near Alaer in south Xinjiang. During six high wind events in spring of 2012 and 2013, they found monthly soil loss was 0.26 and $0.15 \mathrm{~kg} \mathrm{~m}^{-2}$ in April and May, respectively. Pi et al. (2019) quantified wind erosion potential in Xinjiang Province including Alaer and the nine cotton sites of the study (table 1). They found average wind erosion potential across the nine cotton sites (table 1) was three times greater than that in Alaer. Based on this proportion, average monthly soil loss across the nine cotton sites should be about 0.78 and $0.45 \mathrm{~kg}$ $\mathrm{m}^{-2}$ in April and May. However, the simulated average monthly soil loss was 1.89 and 1.19 $\mathrm{kg} \mathrm{m}^{-2}$ in April and May across the nine cotton sites over the two years. That was to say, the simulated soil loss was potentially $150 \%$ higher than measured soil loss. Nonetheless, the measured soil loss by Zheng et al. (2016) observed soil loss from discrete high wind events, but lower loss events were missed, and thus resulted in a relatively lower monthly soil loss as compared with simulation.

Other evidence is noted that WEPS simulated the soil loss in response to climate change in this study well. We found the greater annual soil loss frequently occurred in years when the frequency of dust events was high (figure 5a). For example, the highest annual mean total soil loss and PM10 emissions (283 and $15.2 \mathrm{~kg} \mathrm{~m}^{-2}$ ) occurred in 1982 , during which dust storms $\left(9 \mathrm{~d} \mathrm{y}^{-1}\right)$, floating dust $\left(6.5 \mathrm{~d} \mathrm{y}^{-1}\right)$, and blowing dust $\left(22.3 \mathrm{~d} \mathrm{y}^{-1}\right)$ were more frequent than other years (figure 5a). There was a strong linkage between simulated annual soil loss and frequency of dust storms based on the regression analysis $(y=$ $\left.0.0225 x+1.30, R^{2}=0.51, P=0.001\right)$. Both simulated annual soil loss and frequency of dust storms appeared to have similar patterns of temporal variation. However, simulated annual soil loss appeared to have the worst relationship with floating dust frequency $(\gamma$ $\left.=0.007 x+1.667, R^{2}=0.13, P=0.012\right)$.

\section{Figure 5}

(a) Time series of mean frequency of dust events (dust storm frequency, floating dust frequency, and blowing dust frequency) and annual mean simulated soil loss, and (b) regression analysis between frequency of dust events and annual mean simulated soil loss and (c) between simulated erosion frequency and frequency of dust events across 11 meteorological stations in Junggar Basin of north Xinjiang.

(a)
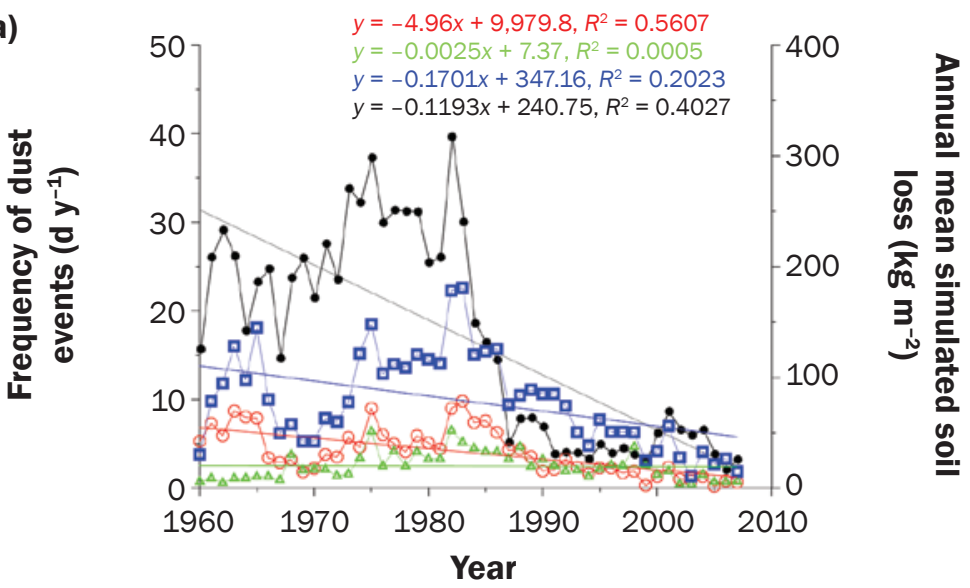

(b)

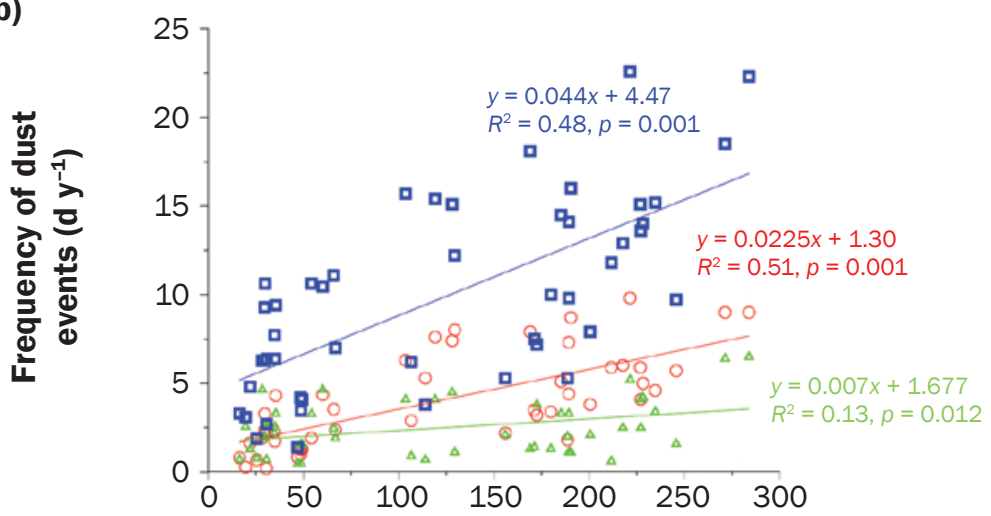

Annual mean simulated soil loss $\left(\mathrm{kg} \mathrm{m}^{-2}\right)$

(c)

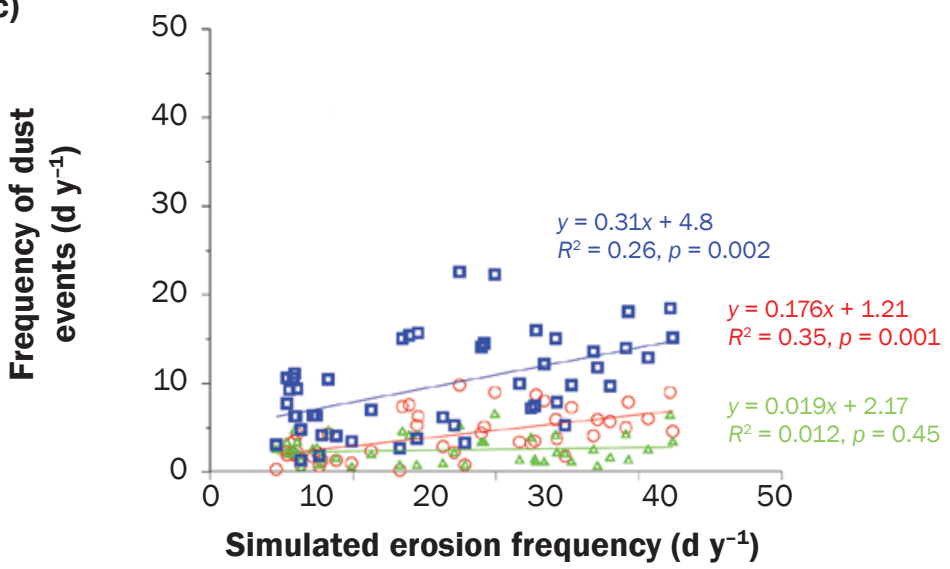

\section{Legend}

$\circ-0$ Dust storm

$\ldots$ Floating dust - a Blowing dust $\cdots$ Soil loss 
This is not surprising because floating dust is dust that is derived from upwind $10 \mathrm{~km}$ dust hotspot source areas, whereas dust storms are comprised of dust emitted from local sources $(<1 \mathrm{~km}$ ) (Xiao et al. 2008; Kurosaki and Mikami 2005). Simulated soil loss refers to the detachment of sediment by local wind, thus more prone to relate with the frequency of dust storms. Dust events in the basin were dominated by blowing dust $(0.1$ to $10 \mathrm{~km}$ in visibility) (figure 5a), and the pattern appeared to be consistent with simulated results because soil loss was driven by suspension rather than creep, saltation, or PM10 processes (see section "Spatial Distribution of Soil Loss and PM10 Emissions"). Creep and saltation are the erosive particles $>0.1 \mathrm{~mm}$, which creep or bounce along soil surfaces (Shao 2008), thus they are hard to be carried by the wind over large distances; however, fine particles such as PM10 $(0.01 \mathrm{~mm})$ can travel hundreds of kilometers (Chung et al. 2013) or around the world (Creamean et al. 2013) before being deposited back to the land or ocean surface. In contrast, coarse suspension particles ( 0.01 to $0.1 \mathrm{~mm}$ ) can be carried into atmosphere, suspending few hours, and transporting a few or dozens of kilometers (Shao 2008). Similar relationships were found between simulated frequency of erosion and observed frequency of dust events. Although weak relationships were found between simulated frequency of erosion and observed frequency of dust storm, blowing dust, and floating dust events, we found the coefficient of regression between simulated frequency of erosion and observed frequency of dust storms was relatively high as compared to observed frequency of blowing dust and floating dust events (figure 5c). One of the reasons for these low coefficients of regression was the high variability in daily simulated erosion (table 2). Some simulated erosion events were relatively large, which caused a dust storm. However, some simulated erosion events were relatively small, which may not have caused a dust storm but could have generated a blowing dust or floating dust event. This indicated that wind erosion risk varied not only among stations and years, but also days.

Significance of Wind Erosion for the Agricultural Land in Response to Climate Change. Soil loss and PM10 emissions from agricultural lands in the Junggar Basin significantly decreased during the past six decades. Evidence from this study indicated that climate change in this region is correlated with wind erosion intensity and land degradation. However, soil loss in suspension dominates the erosion process on agricultural lands in the study area, and considerable suspension particles still are a big threat for human and environmental health in terms of air pollution. Wind erosion processes such as creep, saltation, and suspension were directly determined by soil erodible aggregates. Conservation practices aiming to increase aggregate size and stability such as no-till or minimum tillage operations, should be given priority in agricultural lands by land managers to control suspension risk and alter the wind erosion processes.

\section{Summary and Conclusions}

Wind erosion risk associated with soil, crop, and weather was evaluated in terms of simulating soil loss and PM10 emission in response to climate in the Junggar Basin. Simulated annual soil loss and PM10 emission decreased from 1958 to 2018; this trend was significantly associated with the decreasing wind speed and solar radiation as well as increasing precipitation and temperature. Wind erosion risk varied among sites and years, and the highest dust source regions shifted from year to year within the basin. However, the southeast part of the basin appeared to have a greater wind erosion risk than other parts of the basin. Projects to control wind erosion risk and combat dust emission should be given priority in the southeast part of the basin by land managers.

Topography and elevation were not factors impacting wind erosion in the current WEPS, and there was not significant relationship between annual total soil loss and elevation on the basis of the low coefficient of regression $\left(y=0.189 x-14.8, R^{2}=0.25\right.$ $P=0.12)$. However, regression analysis of annual average wind speed as a function of elevation $\left(y=399.6 x-249.3, R^{2}=0.78\right.$, $P<0.001)$ indicated elevation was a factor influencing wind speed. The higher elevation appeared to correspond with the greater wind speed, although the higher elevation also appeared to correspond with the greater precipitation, and there was an acceptable relationship between annual precipitation and elevation $\left(y=0.135 x+128.8, R^{2}=\right.$ $0.50)$. This indicated that topography and elevation were not factors directly impacting wind erosion, but process-based factors indirectly impact soil wind erosion through impacting the wind speed or precipitation.

\section{Acknowledgements}

We acknowledge financial support from the Highlevel Talent Recruitment Program of Xinjiang Uygur Autonomous Region, "the Belt and Road" Special Project (grant E0310201). The authors declare that they have no conflicts of interest. All data included in this study are available upon request by contact with the corresponding author. Climate and weather data used in this paper are available from China Meteorological Data Network (CMDN) (http://data.cma.cn/site/index.html); crop land types and soil data are available from the Cold and Arid Regions Science Data Center, National Natural Science Foundation of China (http://westdc.westgis.ac.cn).

\section{References}

Burri, K., C. Gromke, M. Lehning, and F. Graf. 2011 Aeolian sediment transport over vegetation canopies: A wind tunnel study with live plants. Aeolian Research 3(2):205-213.

Chen, Z.H., G.Y. Shi, and H.Z. Che. 2005. Analysis of the solar radiation of Xinjiang Uygur Autonomous Region in recent 40 years. Arid Land Geography 28:734-739.

Chen, L., H. Zhao, B. Han, and Z. Bai. 2014. Combined use of WEPS and Models-3/CMAQ for simulating wind erosion source emission and its environmental impact. Science of the Total Environment 466-467:762-769. https://doi.org/10.1016/j.scitotenv.2013.07.090.

Cheng,W.M.,H.X. Chai, C.H.Zhou, and X. Chen. 2009.The spatial distribution patterns of digital geomorphology in Xinjiang 28:1157-1169.

Cheng, J., F. Jiang, C. Xue, G. Xin, K. Li, and Y. Yang. 2015 Characteristics of the disastrous wind-sand environment along railways in the Gobi area of Xinjiang, China. Atmospheric Environment 102:344-354. https://doi. org/10.1016/j.atmosenv.2014.12.018.

Chung, S.H., F.L. Herron-Thorpe, B.K. Lamb, T.M. VanReken, J.K. Vaughan, J.C. Gao, L.E. Wagner, F. Fox. 2013. Application of the Wind Erosion Prediction System in the AIRPACT Regional Air Quality Modeling Framework. Transactions of the ASABE 56: 625-641. https://doi.org/10.13031/2013.42674.

Creamean, J.M., K.J. Suski, D. Rosenfeld, A. Cazorla, P.J. DeMott, R.C. Sullivan, A.B. White, F.M. Ralph, P. Minnis, J.M. Comstock, J.M. Tomlinson, and K.A. Prather. 2013. Dust and biological aerosols from the Sahara and Asia influence precipitation in the western U.S. Science 339:1572-1578. https://doi.org/10.1126/ science. 1227279 .

Deng, H., Y. Chen, H. Wang, and S. Zhang. 2015. Climate change with elevation and its potential impact on water resources in the Tianshan Mountains, Central Asia. Global and Planetary Change 135(December 2015):28-37 
Ding, Z.L., J.M. Sun, S.L. Yang, and T.S. Liu. 1998. Preliminary magnetostratigraphy of a thick eolian red clay-loess sequence at Lingtai, the Chinese Loess Plateau. Geophysical Research Letters 25:1225-1228. https://doi.org/10.1029/98GL00836.

Dong, Z.B., X.M. Wang, and L.Y. Liu. 2000. Wind erosion in arid and semiarid China: An overview. Journal of Soil and Water Conservation 55(4):439-444.

Du, H., T. Wang, X. Xue, and S. Li. 2018. Modelling of sand/ dust emission in Northern China from 2001 to 2014. Geoderma 330:162-176. https://doi.org/10.1016/j. geoderma.2018.05.038.

Fang, X., Z. Shi, S. Yang, M. Yan, J. Li, and P. Jiang. 2002. Loess in the Tian Shan and its implications for the development of the Gurbantunggut Desert and drying of northern Xinjiang. Chinese Science Bulletin 47:1381-1387. https://doi.org/10.1360/02tb9305.

Feng, G., and B. Sharratt. 2005. Sensitivity analysis of soil and PM10 loss in WEPS using the LHS-OAT method. Transactions of the ASABE 48:1409-1420.

Feng, G., and B. Sharratt. 2009. Evaluation of the SWEEP model during high winds on the Columbia Plateau. Earth Surface Processes and Landforms 34:1461-1468. https://doi.org/10.1002/esp.1818.

Feng, Y., G. Luo, L. Lu, D. Zhou, Q. Han, W. Xu, C. Yin, L. Zhu, L. Dai, Y. Li, and C. Li. 2011. Effects of land use change on landscape pattern of the Manas River watershed in Xinjiang, China. Environmental Earth Sciences 64:2067-2077. https://doi.org/10.1007/ s12665-011-1029-5.

Fryrear, D.W., A. Saleh, J.D. Bilbro, H.M. Schomberg, J.E. Stout, and T.M. Zobeck. 1998. Revised Wind Erosion Equation (RWEQ). Technical Bulletin No. 1. Lubbock, TX: Wind Erosion and Water Conservation Research Unit, USDA Agricultural Research Service, Southern Plains Area Cropping Systems Research Laboratory.

Fu, G., J. Yu, X. Yu, R. Ouyang, Y. Zhang, P. Wang, W. Liu, and L. Min. 2013. Temporal variation of extreme rainfall events in China, 1961-2009. Journal of Hydrology 487:48-59.

Funk, R., E. Skidmore, and L. Hagen. 2004. Comparison of wind erosion measurements in Germany with simulated soil losses by WEPS. Environmental Modelling and Software 19:177-183. https://doi.org/10.1016/ S1364-8152(03)00120-8.

Grace, J. 1988. Temperature as a determinant of plant productivity. Symposia of the Society for Experimental Biology 42:91-107.

Guo, L., and L. Li. 2015. Variation of the proportion of precipitation occurring as snow in the Tian Shan Mountains, China. International Journal of Climatology 35:1379-1393. https://doi.org/10.1002/joc.4063.

Hagen, L.J. 2004. Evaluation of the Wind Erosion Prediction System (WEPS) erosion submodel on cropland fields. Environmental Modelling \& Software 19:171-176. https://doi.org/10.1016/S1364-8152(03)00119-1.
Hamed, K.H. 2008. Trend detection in hydrologic data: The Mann-Kendall trend test under the scaling hypothesis. Journal of Hydrology 349(3):350-363.

He, B.B., S.Yu, W. Cao, and J.C. Wu. 2020. Characteristics of Climate Change in Northern Xinjiang in 1961-2017, China. Chinese Geographical Science 30(02):249-265.

Huang, W., S.-Q. Chang, C.-L. Xie, and Z.-P. Zhang. 2017. Moisture sources of extreme summer precipitation events in North Xinjiang and their relationship with atmospheric circulation. Advances in Climate Change Research 8:12-17. https://doi.org/10.1016/j. accre.2017.02.001.

IPCC (Intergovernmental Panel on Climate Change). 2007. Climate Change 2007 - The Physical Science Basis: Working Group I Contribution to the Fourth Assessment Report of the IPCC. Cambridge, UK: Cambridge University Press.

Kurosaki, Y., and M. Mikami. 2005. Regional difference in the characteristic of dust event in East Asia: Relationship among dust outbreak, surface wind, and land surface condition. Journal of the Meteorological Society of Japan 83A:1-18. https://doi.org/10.1029/2003JD003913.

Lawrence, M.G. 2005. The relationship between relative humidity and the dewpoint temperature in moist air: A simple conversion and applications. Bulletin of the American Meteorological Society 86:225-234. https:// doi.org/10.1175/BAMS-86-2-225.

Li, N., H. Lin, T.Wang,Y. Li,Y. Liu, X. Chen, and X. Hu. 2020a. Impact of climate change on cotton growth and yields in Xinjiang, China. Field Crops Research 247:107590. https://doi.org/10.1016/j.fcr.2019.107590.

Li, J., X. Ma, and C. Zhang. 2020b. Predicting the spatiotemporal variation in soil wind erosion across Central Asia in response to climate change in the 21st century. Science of the Total Environment 709:136060. https://doi.org/10.1016/j.scitotenv.2019.136060.

Li, Y., W. Shi, A. Aydin, M.A. Beroya-Eitner, and G. Gao. 2020c. Loess genesis and worldwide distribution. Earth-Science Reviews 201:102947. https://doi. org/10.1016/j.earscirev.2019.102947.

Li, S., Q. Wang, and L. Li. 2016. Interdecadal variations of pan-evaporation at the southern and northern slopes of the Tianshan Mountains, China. Journal of Arid Land 8:832-845. https://doi.org/10.1007/ s40333-016-0018-7.

Liu, D. 1985. Loess and the Environment. Beijing: China Ocean Press.

Liu, R., L.-P. Pan, G.D. Jenerette, Q.-X. Wang, E. Cieraad, andY. Li. 2012. High efficiency in water use and carbon gain in a wet year for a desert halophyte community. Agricultural and Forest Meteorology 162-163:127-135. https://doi.org/10.1016/j.agrformet.2012.04.015.

Mckenna Neuman, C. 2003. Effects of temperature and humidity upon the entrainment of sedimentary particles by wind. Boundary-Layer Meteorology 108:61-89. https://doi.org/10.1023/A:1023035201953.
Nearing, M., L. Deer-Ascough, and J.M. Laflen. 1990. Sensitivity analysis of the WEPP hillslope profile erosion model. Transactions of the ASAE 33(3):839-949.

Pécsi, M. 1990. Loess is not just the accumulation of dust. Quaternary International 7-8:1-21. https://doi. org/10.1016/1040-6182(90)90034-2.

Peng, S., Y. Ding, W. Liu, and Z. Li. 2019. 1 km monthly temperature and precipitation dataset for China from 1901 to 2017. Earth System Science Data 11(4):1931-1946.

Pi, H., G. Feng, B.S. Sharratt, X. Li, and Z. Zheng. 2014. Validation of SWEEP for contrasting agricultural land use types in the Tarim Basin. Soil Science 179(9):433445. https://doi.org/10.1097/SS.0000000000000083.

Pi, H., B. Sharratt, G. Feng, and J. Lei. 2017a. Evaluation of two empirical wind erosion models in arid and semiarid regions of China and the USA. Environmental Modelling and Software 91:28-46.

Pi, H., B. Sharratt, G. Feng, J. Lei, X. Li, and Z. Zheng. 2016. Validation of SWEEP for creep, saltation, and suspension in a desert-oasis ecotone. Aeolian Research 20:157-168. https://doi.org/10.1016/j.aeolia.2016.01.006.

Pi, H., B. Sharratt, and J. Lei. 2019. Wind erosion and dust emissions in central Asia: Spatiotemporal simulations in a typical dust year. Earth Surface Processes and Landforms 44:521-534. https://doi.org/10.1002/esp.4514.

Pi, H., B. Sharratt, and J. Lei. 2017b. Atmospheric dust events in central Asia: Relationship to wind, soil type, and land use. Journal of Geophysical Research: Atmospheres 122:6652-6671. https://doi. org/10.1002/2016JD026314.

Pi, H., B. Sharratt, and J. Lei. 2017c. Windblown sediment transport and loss in a desert-oasis ecotone in the Tarim Basin. Scientific Reports 7(7723):1-8. https://doi. org/10.1038/s41598-017-04971-4.

Pi, H., N.P. Webb, D.R. Huggins, and B. Sharratt. 2020. Critical standing crop residue amounts for wind erosion control in the inland Pacific Northwest, USA. CATENA 195:104742.

Raei, B., A. Ahmadi, M.R. Neyshaburi, M.A. Ghorbani, and F. Asadzadeh. 2021. Comparative evaluation of the whale optimization algorithm and backpropagation for training neural networks to model soil wind erodibility. Arabian Journal of Geosciences 14(1):29.

Qi, J.Y., B. Bateer, and M. Kalibir. 2020. Climate response of water demand variation in spring wheat at different growth stages in Northern Xinjiang. Journal of Triticeae Crops (03):1-8.

Qian,Y.-B., Z.-N.Wu, Q.Yang, L.-Y.Zhang, and X.-Y.Wang. 2007. Ground-surface conditions of sand-dust event occurrences in the southern Junggar Basin of Xinjiang, China. Journal of Arid Environments 70:49-62. https:// doi.org/10.1016/j.jaridenv.2006.12.001.

Sala, O.E., W.J. Parton, L.A. Joyce, and W.K. Lauenroth. 1988. Primary production of the Central Grassland Region of the United States. Ecology 69:40-45. https://doi. org/10.2307/1943158. 
Scott, D., C.M. Hall, and S. Gössling. 2016. A review of the IPCC Fifth Assessment and implications for tourism sector climate resilience and decarbonization. Journal of Sustainable Tourism 24:8-30. https://doi.org/10.1080/ 09669582.2015.1062021.

Shao, Y. 2008. Physics and Modelling of Wind Erosion. Berlin: Springer Science \& Business Media.

Shao, Y., and C.H. Dong. 2006. A review on East Asian dust storm climate, modelling and monitoring. Global and Planetary Change 52:1-22. https://doi.org/10.1016/j. gloplacha.2006.02.011.

Shao, Y., M. Klose, and K.-H. Wyrwoll. 2013. Recent global dust trend and connections to climate forcing. Journal of Geophysical Research: Atmospheres 118(19):11-107. https://doi.org/10.1002/jgrd.50836.

Shao, Y., and J.Wang. 2003. A climatology of Northeast Asian dust events. Meteorologische Zeitschrift 12:187-196 https://doi.org/10.1127/0941-2948/2003/0012-0187.

Sharratt, B.S., J. Tatarko, J.T. Abatzoglou, F.A. Fox, and D Huggins. 2015. Implications of climate change on wind erosion of agricultural lands in the Columbia plateau. Weather and Climate Extremes 10:20-31. https://doi. org/10.1016/j.wace.2015.06.001

Skidmore, E.L. 1986. Wind erosion climatic erosivity. Climatic Change 9:195-208. https://doi.org/10.1007/ BF00140536.

Skidmore, E.L., and J. Tatarko. 1990. Stochastic wind simulation for erosion modeling. Transactions of the ASABE 33(6):1893-1899.

Song, H., K. Zhang, S. Piao, and S. Wan. 2016. Spatial and temporal variations of spring dust emissions in northern China over the last 30 years. Atmospheric Environment 126:117-127. https://doi.org/10.1016/j. atmosenv.2015.11.052.

USDA ARS (Agricultural Research Service). 2020. The Wind Erosion Prediction System (WEPS): Technical Documentation, ed. J. Tatarko, 533. USDA Agriculture Handbook 727. Beltsville, MD: USDA ARS. https:// naldc.nal.usda.gov/catalog/7105679.

Van Pelt, R.S., S.X. Hushmurodov, R.L. Baumhardt, A. Chappell, M.A. Nearing, V.O. Polyakov, and J.E. Strack. 2017. The reduction of partitioned wind and water erosion by conservation agriculture. Catena 148:160-167.

Wagner, L.E. 2013. A history of Wind Erosion Prediction Models in the United States Department of Agriculture: The Wind Erosion Prediction System (WEPS). Aeolian Research 10:9-24. https://doi.org/10.1016/j. aeolia.2012.10.001

Wang, T., J. Qu, Y. Ling, B. Liu, and J. Xiao. 2018. Shelter effect efficacy of sand fences:A comparison of systems in a wind tunnel. Aeolian Research 30:32-40. https://doi. org/10.1016/j.aeolia.2017.11.004.

Webb, N.P., N.A. Marshall, L.C. Stringer, M.S. Reed, A Chappell, and J.E. Herrick. 2017. Land degradation and climate change: Building climate resilience in agriculture. Frontiers in Ecology and the Environment 15:450-459. https://doi.org/10.1002/fee.1530.

Webb, N.P., G.S. Okin, and S. Brown. 2014. The effect of roughness elements on wind erosion:The importance of surface shear stress distribution. Journal of Geophysical Research:Atmospheres 119(10):6066-6084.

Wu, Z., H. Zhang, C.M. Krause, and N.S. Cobb. 2010. Climate change and human activities: A case study in Xinjiang, China. Climatic Change 99:457-472. https:// doi.org/10.1007/s10584-009-9760-6.

Xiao, F., C. Zhou, and Y. Liao. 2008. Dust storms evolution in Taklimakan Desert and its correlation with climatic parameters. Journal of Geographical Sciences 18:415424. https://doi.org/10.1007/s11442-008-0415-8.

Yang, X., F.Yang, X. Liu, W. Huo, Q. He, A. Mamtimin, and Q. Zhang. 2016. Comparison of horizontal dust fluxes simulated with two dust emission schemes based on field experiments in Xinjiang, China.Theoretical and Applied Climatology 126:223-231. https://doi.org/10.1007/ s00704-015-1573-0.

Zhang, G., C. Azorin-Molina, P. Shi, D. Lin, J.A. Guijarro, F Kong, and D. Chen. 2019. Impact of near-surface wind speed variability on wind erosion in the eastern agropastoral transitional zone of Northern China, 1982-2016. Agricultural and Forest Meteorology 271:102-115. https://doi.org/10.1016/j.agrformet.2019.02.039.

Zheng, Z., B. Sharratt, G. Feng, X. Li, and H. Pi. 2016. Wind erosion of cropland in the northwestern Tarim Basin. Soil Science Society of America Journal 80:672. https:// doi.org/10.2136/sssaj2015.07.0259.

Zhou, Z., and G. Zhang. 2003. Typical severe dust storms in northern China during 1954-2002. Chinese Science Bulletin 48:2366-2370. https://doi org/10.1360/03wd0029 